\title{
Soil Pollution with Lead: Geochemistry, Food Safety Issues and Reclamation Options - A Review
}

\author{
Neelam Yadav', Ankita Trivedi', S.S. Yadav ${ }^{3 *}$, D.K. Yadav', \\ V.K. Yadav ${ }^{4}$ and Nagesh Yadav \\ ${ }^{1}$ Institute of Agricultural Sciences, Banaras Hindu University, Varanasi, India \\ ${ }^{2}$ ICAR-Indian Agricultural Research Institute, New Delhi, India \\ ${ }^{3}$ S.K.N. University of Agricultural Sciences, Jobner, India \\ ${ }^{4}$ Rajasthan College of Agriculture, MPUAT, Udaipur, India \\ *Corresponding author
}

\begin{tabular}{|l|}
\hline Key w o r d s \\
Soil Pollution, \\
Lead, \\
Geochemistry, \\
Food Safety
\end{tabular}

\section{A B S T R A C T}

Lead $(\mathrm{Pb})$ exposure is estimated to account for $0.6 \%$ of the global burden of disease with the highest burden in developing regions. Lead is considered as general protoplasmic poison, which is slow acting, cumulative and subtle. The use of leaded gasoline, discharges from industrial activities and other sources, and deposition by rainfall or dry fall can greatly influence the availability of $\mathrm{Pb}$ in soil, water, and other environments. Most of the $\mathrm{Pb}$ in plants and soil surface are anthropogenic origin. As many of the $\mathrm{Pb}$ pollutants are indispensible for human life, soil contamination with lead is not likely to decrease in near future. Severe $\mathrm{Pb}$ contamination in soils may cause a variety of environmental problems including loss of vegetation, groundwater contamination, and $\mathrm{Pb}$ toxicity in plants, animals, and humans. The cation exchange capacity, $\mathrm{pH}$, organic matter, clay and $\mathrm{CaCO}_{3}$ content can be considered as the most important factors affecting $\mathrm{Pb}$ adsorption capacity of soils. Lead may cause the toxic effects on gastrointestinal, muscular, reproductive and neurological systems. $\mathrm{Pb}$ is having long half-life in biological systems and plants facilitate entry of $\mathrm{Pb}$ in food chains of man and animals. It may enter into our body through ingestion of food or through the blood stream (Johnson, 1998). Recently, accumulator plants for reclaiming $\mathrm{Pb}$ polluted soils have increasingly been used. Also, application of phosphate has been reported to be effective in immobilising $\mathrm{Pb}$ in soil, leading to reduction in its transfer from soil to plant. Among various reclamation techniques applied for heavy metal, phytoextraction has emerged as less costly, effective method of in situ reclamation. Use of synthetic chelates has improved phytoextraction. Lead with synthetic chelate forms soluble bio-available compounds which may leach down the soil profile and cause ground or water contamination. Hence, approaches of re-vegetation and reclamation, involving both ameliorative and adaptive strategies to allow plant establishment and encourage subsequent vegetation, have emerged.

\section{Introduction}

Lead $(\mathrm{Pb})$ is a naturally occurring toxic heavy metal found in the earth's crust. Its widespread use has resulted in extensive environmental contamination, human exposure and significant public health problems in many parts of the world. Lead is a cumulative toxicant that affects multiple body systems and is particularly harmful to young children. WHO has identified lead as one of the ten chemicals of major public health concern, needing action to protect the health of workers, children and women of reproductive 
age. As many of the lead pollutants are indispensable for human life, soil contamination with lead is not likely to decrease in the near future. It is non-biodegradable, toxic heavy metal and it has become a global health issue. Due to strong binding of most trace metals to soil constituents, and their limited transport, trace metals have long residence time in soils (Hesterberg, 1998) and concentrations can become elevated above back ground levels and threaten plant, animal, and environmental health. As many of the $\mathrm{Pb}$ pollutants are indispensible for human life, soil contamination with lead is not likely to decrease in near future (Yang et al., 2000). $\mathrm{The} \mathrm{Pb}$ loading rate in soil exceeded its natural removal rate by approximately 20 -fold or more (Nriagu, 1990).

\section{Sources of lead in soil}

The terrestrial abundance of $\mathrm{Pb}$ indicates a tendency for $\mathrm{Pb}$ to concentrate in the acid series of magmatic rocks and argillaceous sediments in which the common $\mathrm{Pb}$ concentrations range from 10 to $40 \mathrm{ppm}$, while in ultramafic rocks and calcareous sediments its range is from 0.1 to $10 \mathrm{ppm}$. The average abundance of $\mathrm{Pb}$ in the Earth's crust is estimated at about $15 \mathrm{ppm}$. In the terrestrial environment, two kinds of $\mathrm{Pb}$ are known: primary and secondary. Primary $\mathrm{Pb}$ is of geogenic origin and was incorporated into minerals at the time of their formation, and secondary $\mathrm{Pb}$ is of a radiogenic origin from the decay of $\mathrm{U}$ and $\mathrm{Th}$. The ratio of $\mathrm{Pb}$ of various origins is used for dating the host materials. Other anthropogenic sources including old house paints, tetraethyl lead in gasoline, water coming from leaded pipes, melting and smelting industries, sewage and sludge, contaminated water are responsible for depositing lead on soil.

In 2004, an estimate of 3.15 million tonnes of lead were extracted from earth's crust by human and brought into circulation by society. The only comprehensive assessment of global anthropogenic lead release to soil and waste dates back to 1983 which estimated that $6,00,000$ to $16,60,000$ tonnes of lead directed to waste deposits or released to soil. Around $2,00,000$ to $2,60,000$ tonnes of lead is again deposited from atmosphere to land. At least 10 $\%$ of the consumption is accumulated in landfills.

\section{Forms lead in soil}

The form of $\mathrm{Pb}$ emitted by automobiles is rapidly gets transformed to $\mathrm{PbSO}_{4}$ in the atmosphere. $\mathrm{PbSO}_{4}$ is quickly converted by soil chemical processes to other, noncrystalline, species of $\mathrm{Pb}$. In calcareous soils, $\mathrm{PbSO}_{4}$ and $\mathrm{PbCO}_{3}$ forms are generally present, but it contributes for $<5 \%$ of the soil $\mathrm{Pb}$. $\mathrm{Pb}^{4+}$ cannot persist in soils because it is reduced to $\mathrm{Pb}^{2+}$. Also, $\mathrm{PbSO}_{4}$ cannot persist because it is readily oxidized. Lead tends to accumulate in the surface ground layer and its concentration decreases with soil depth. Lead concentrations decrease rapidly in soil with distance from streets and highways.Soils characterized by high amount of organic matter, swelling clay mineral and calcareous subsoil are suitable medium to immobilize a significant lead pollution. Lead is commonly reported to be the least mobile amongst the other heavy metals (Kabata-Pendias, 1993). The largest part of lead is bound to the residual phases (42\%), and $19 \%$ and $27 \%$ of lead to the organic matter and $\mathrm{Fe}-\mathrm{Mn}$ oxides, respectively. The role of exchangeable and specifically adsorbed lead is the less significant $(12 \%)$. In the horizon with high clay mineral content (B horizon) the role of residual phases increases (56\%), while the amount of lead bound to $\mathrm{Fe}-\mathrm{Mn}$ oxides decreases (22\%), and its amount bound to organic matter is the same (20\%) as compared to the A1 horizon. The role of exchangeable and specifically adsorbed lead in this horizon is negligible (2\%). In the carbonate containing 
C horizon the amount of lead bound to residual phases is the most significant (63\%). The role of organic matter slightly decreases (16\%), while the amount of lead bound to FeMn oxides is the same (21\%) as compared to B horizon. There was no measurable lead in the exchangeable and specifically fraction in the $\mathrm{C}$ horizon

According to the experiment carried out by Johnson et al., (1998), it was seen that organic Oa horizon contained maximum concentration of labile $\mathrm{Pb}$. Among the mineral horizon, Bs1 horizon contained maximum concentration of $\mathrm{Pb}$. Overall with increasing depth, concentration of $\mathrm{Pb}$ was found to be in more tightly bound form. Organically bound form of $\mathrm{Pb}$ is more in the upper Oa horizon whereas amorphous oxide bound was found in maximum concentration in the lower $\mathrm{C}$ horizon. Inorganically bound form of $\mathrm{Pb}$ was more in the lower $\mathrm{C}$ horizon as compared to other horizon. Exchangeable+ soluble form of $\mathrm{Pb}$ which is the most easily available form of $\mathrm{Pb}$ was present in upper $\mathrm{Oa}$ horizon. The concentration of heavy metals in the solution phase is of major importance for all ecological considerations because plants take up the available metals from the soil solution, and the transport of metals within the soil or even to the groundwater also depends on the metal concentration of the solution phase. However, the processes which determine the concentration of heavy metals in the soil solution are not yet fully understood. Changes in soil water content, departures from equilibrium or steady-state to non-equilibrium conditions, and changes in the activity of microorganisms which influence redox conditions, contents of soluble chelating agents, and the composition of soil atmosphere require simultaneous consideration. These processes moderate the reactions of heavy metals such as precipitation- dissolution, adsorptiondesorption, and complex and ion-pair formation in relation to the $\mathrm{pH}$ and thus influence the distribution of the various metal species in the solid phases of the soil and in the soil solution.

\section{Factors affecting mobility of $\mathrm{Pb}$ in soil}

The cation exchange capacity, $\mathrm{pH}$, organic matter, clay and $\mathrm{CaCO}_{3}$ content can be considered as the most important factors responsible for the adsorption capacity of soils for $\mathrm{Pb}$ (Adhikari and Singh, 2003). Various factors affecting mobility of $\mathrm{Pb}$ in soil are enlisted below

$\mathrm{pH}$

Soil organic matter

Soil granulometry

Phosphorus addition

Presence of $\mathrm{CaCO}_{3}$

\section{Lead in ocean}

Recent work on lead suggests that the ocean may provide a central role for lead transport and distribution along the Eurasian Basin boundaries of the Arctic Ocean (AMAP, 2004). The residence time of lead in surface water, which is relatively short ( $<5$ years), is still long enough to permit transfer of contaminant lead from the North Atlantic and Nordic Seas into the Arctic (Macdonald et al., 2005) (Table 1).

\section{Lead determination in soil}

After collection of soil sample, it is disaggregated, sieved and dried. Then $\mathrm{Pb}$ is extracted using various extractants. After extraction, instrumental analysis is done. Neutral salt extraction with $\mathrm{CaCl}_{2}, \mathrm{NH}_{4} \mathrm{Cl}$ (Qian et al., 1995) (Krishnamurti et al., 2000) and $\mathrm{NaNO}_{3}$ (Gupta and Aten, 1993) provide the most useful indication of metal phytoavailability and is more effective for estimating plant availability. Extractable $\mathrm{Pb}$ in 
soil generally provides better indication of $\mathrm{Pb}$ availability to plants (Risser and Baker, 1990; Krishnamurti et al., 1995).

\section{Fate of lead and its transport in agriculture}

The fate and toxicity of trace metals in soils is dictated by the chemical form in which they are present within soils. These general forms include water soluble metals (i.e., free ions, inorganic or organic complexes), exchangeable metals, metals precipitated as inorganic compounds, metals complexed with humic materials, metals bound to hydrous oxides and layer silicate minerals, metals precipitated as insoluble sulfides, and metals bound within the structure of primary minerals (Gambrell, 1994). Lead may enter into the food chain either by deposition on surface of edible part of plant or it may get deposited on soil surface and finally enters to the plant part by uptake of plant root. Automobile exhausts, old house paint, bullets, batteries, e-waste etc are among the various sources of $\mathrm{Pb}$ which gets deposited either on plant or on soil surfaces. Lead contamination in paddy soils resulted in soil fertility deterioration and rice yield and quality decline (Majer et al., 2002). Paddy is also staple food of most of the world's population.

\section{Lead uptake by plant}

Lead is available to plants from soil and aerosol sources. Lead uptake studies in plants have demonstrated that roots have ability to take up significant quantities of $\mathrm{Pb}$ while simultaneously greatly restricting it's above ground translocation to plant (Lane and Martin., 1977). Lead moves predominantly into the root apoplast and thereby in a radial manner across the cortex and accumulates near the endodermis. The endodermis acts as partial barrier to the movement of root and shoot. This may in part account for the reports of higher accumulation of $\mathrm{Pb}$ in roots as compared to shoots (Sharma and Dubey, 2005). It appears that casparian strips of endodermis are the major limiting factor restricting $\mathrm{Pb}$ transport across endodermis into the central cylindrical tissue. This provides evidence that $\mathrm{Pb}$ moves into symplast. In general, the apparent concentration of $\mathrm{Pb}$ in aerial parts of the plant decreases as the distance from plant increases. This occurs due to greater localization of $\mathrm{Pb}$ in the cell walls of root than any other plant part. It is seen that accumulation of $\mathrm{Pb}$ in different plant parts can be as follows: Root > Shoot > Grain.

In this experiment it was seen that accumulation rate decreased with increasing the concentration of $\mathrm{Pb}$ in soil. Thus vegetation showed high relative uptake in area of low soil concentration and low relative uptake in areas of high concentration. It also showed that there is no direct correlation with the amount of $\mathrm{Pb}$ present in the soil and the amount taken up by plant (Table 2).

\section{Lead in food}

Foods such as fruits, vegetables meat, seafood soft drink and wine may contain significant amount of lead. Cigarette smoke also contains small amounts of lead. As per literature review it is found that has no essential function in the human body, it can merely do the harm after uptake from, air, or water. Lead can cause several unwanted effects such as a rise in blood pressure, kidney damage, Brain damage, Decline fertility of men through sperm damage, diminishing learning ability of children, Behavioral disruption of children, etc. (Tiwari et al., 2013). In older food basket surveys, the influence of lead-soldered tin cans used for storage of food was noticeable. Glazes on ceramics, earthenware, bone china, and porcelain often contain lead and are a potential source of exposure. Vitamin $\mathrm{C}$, Thiamine, taurine (a vitamin $\mathrm{B}_{6} /$ cysteine derivative), folate, vitamin $\mathrm{B}_{12}$, garlic and the 
amino acids methionine and glycine may offer significant advantages to lead exposed individuals with few risks. Calcium, iron, zinc, and selenium along with vitamins $\mathrm{B}_{6}, \mathrm{D}$ and $\mathrm{E}$ offer large advantages along with significant offsetting risks at high doses. Good intakes of phosphorus, magnesium, copper and glutamic acid (glutamate) offer possible smaller advantages with little risk. It must be emphasized that a combination of these nutrients is needed to offset lead's diverse impacts, though if one were to nominate a single nutrient it would probably be vitamin $\mathrm{C}$ since, in spite of some inconsistent results, it has strong, widespread impacts combined with minimal risks for most individuals (the main exception would be individuals with high iron levels, since it increases iron absorption).

\section{Lead in human}

Lead poisoning is also called plumbism, colica pictonum or saturnism. Lead is toxic to humans and affects virtually every system in the body. In 1995 the WHO named skin and muscle as the only two systems left unharmed by $\mathrm{Pb}$ exposure. $\mathrm{Pb}$ mainly enters human body through the digestive tract and respiratory tract, and then goes into the blood circulation in the form of soluble salts, protein complexes or ions, etc. $95 \%$ of the insoluble phosphate lead accumulates in bones. $\mathrm{Pb}$ is strongly proorganizational. It affects and damages many of the body organs and systems, such as kidney, liver, reproductive system, nervous system, urinary system, immune system and the basic physiological processes of cells and gene expression (Su et al., 2014). Young children are particularly vulnerable to the toxic effects of lead and can suffer profound and permanent adverse health effects, particularly affecting the development of the brain and nervous system. Lead also causes long-term harm in adults, including increased risk of high blood pressure and kidney damage. Exposure of pregnant women to high levels of lead can cause miscarriage, stillbirth, premature birth and low birth weight, as well as minor malformations. Research has shown that some $\mathrm{Pb}$ minerals are poorly absorbed by humans ( $\mathrm{PbS}$, chloropyromorphite, while some others are readily absorbed $\left(\mathrm{PbCO}_{3}\right)$. Perhaps the most important factor in $\mathrm{Pb}$ absorption is the presence of food in the stomach/ intestine when the $\mathrm{Pb}$ source is present.

Several research teams evaluated $\mathrm{Pb}$ isotope absorption by human volunteers fed $\mathrm{Pb}$ with meals or specific foods, or on fasting. On fasting, soluble $\mathrm{Pb}$ is absorbed at 50-80\%, usually assumed by EPA to be $50 \%$ for $\mathrm{Pb}$ acetate. But when the $\mathrm{Pb}$ is ingested with a meal, $1 \mathrm{hr}$ before a meal, or up to $4 \mathrm{~h}$ after a meal, absorption falls to the range of $2-5 \%$ of dose (Heard and Chamberlain, 1982; Heard et al., 1983; James et al., 1985). Particular food ingredients ingested with $\mathrm{Pb}$ can greatly reduce $\mathrm{Pb}$ absorption, especially $\mathrm{Ca}$ (Blake and Mann, 1983); Ca is believed to compete with $\mathrm{Pb}$ absorption by a Ca-transport protein in the small intestine, but also to form coprecipitates with phosphate and $\mathrm{Pb} . \mathrm{Pb}$ incorporated in kidney or spinach had quite low bioavailability to adults (Heard et al., 1983).

As noted earlier, a meta-analysis of the contribution of soil versus house dust to blood $\mathrm{Pb}$ of urban children has shown that house dust was considerably more important (Lanphear et al., 1998). Several groups noted that $\mathrm{Pb}$ in mining site soils caused less increase in blood $\mathrm{Pb}$ than did $\mathrm{Pb}$ in smelter site soils (Steele et al., 1990). Davis et al., (1993) found galena and anglesite $\left(\mathrm{PbSO}_{4}\right)$ with rinding in mine waste soils at Butte, MT. The dissolution of $\mathrm{PbSO}_{4}$ was found to be inherently slow compared to the time needed for clearance of the stomach and intestine of children, helping to explain why this form of $\mathrm{Pb}$ caused less uptake into blood (Table 3). 
Table.1 Common values for $\mathrm{Pb}$ concentration $(\mathrm{ppm})$ in various environmental media

\begin{tabular}{|c|c|c|}
\hline Material & Concentration & Range \\
\hline Igneous Rock & 15 & $2-30$ \\
\hline Sandstone & 7 & $1-31$ \\
\hline Limestone & 9 & - \\
\hline Shale & 20 & $16-50$ \\
\hline Coal & 16 & Upto 60 \\
\hline Fly Ash & 170 & $21-220$ \\
\hline Soils (agricultural) & - & $2-300$ \\
\hline Fresh water $(\boldsymbol{\mu g} / \mathbf{L})$ & 3 & $0.06-120$ \\
\hline Sea water $(\boldsymbol{\mu g} / \mathbf{L})$ & 0.03 & $0.03-13$ \\
\hline Sewage, sludge & 1832 & $136-7627$ \\
\hline
\end{tabular}

Table. 2 Lead content in root and shoot of rice seedling of 10 and 20 days in presence of different concentration of $\mathrm{Pb}\left(\mathrm{NO}_{3}\right)_{2}$ in sand culture

\begin{tabular}{|c|c|c|c|}
\hline $\begin{array}{c}\text { Age of seedling } \\
\text { (days) }\end{array}$ & $\begin{array}{l}\text { Concentration of } \\
\mathbf{P b}(\boldsymbol{\mu M})\end{array}$ & $\begin{array}{l}\mathrm{Pb} \text { content }(\mu \mathrm{mol} \mathrm{Pb} / \mathrm{g} \\
\mathrm{DW}) \text { in root }\end{array}$ & $\begin{array}{l}\mathrm{Pb} \text { content }(\mu \mathrm{mol} \\
\mathrm{Pb} / \mathrm{g} \text { DW }) \text { in shoot }\end{array}$ \\
\hline $\mathbf{1 0}$ & 0 & 0 & 0 \\
\hline & 500 & 0.16 & 0.06 \\
\hline & 1000 & 0.72 & 0.22 \\
\hline & 0 & 0 & 0 \\
\hline & 500 & 0.80 & 0.38 \\
\hline & 1000 & 1.22 & 0.72 \\
\hline
\end{tabular}

(Verma and Dubey, 2003, Chopin and Alloway, 2007)

Table.3 Blood lead levels associated with specific biological responses in children

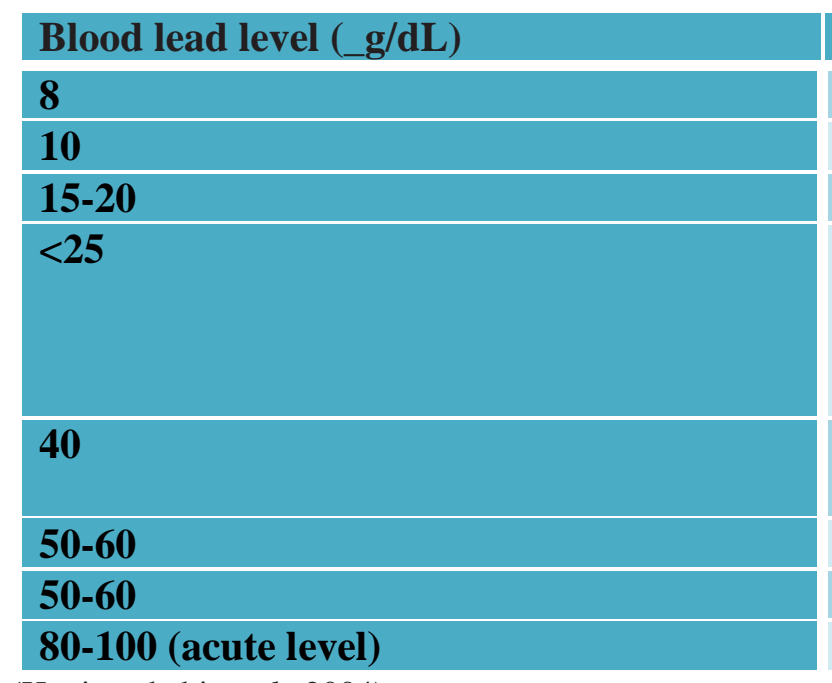

\section{Effect}

Subtle neurological impairment

ALAD inhibition

Erythrocyte protoporphyrin elevation

Verbal IQ, mental development, physical size, and age at physical milestones such as first step, hearing thresholds, and postural sway

Increased urinary ALA excretion, anemia coporporphyrin elevation

Cognitive (central nervous system) deficits

Peripheral neuropathies

Encephalopathic symptoms

(Hettiarachchi et al., 2004) 


\section{Reclamation of lead in soil}

\section{Physical remediation}

Replacement of contaminated soil, soil removal and soil isolation

\section{Chemical remediation}

Application of $\mathrm{CaCO}_{3}$

Application of phosphate

\section{Bioremediation}

Phytoremediation

\section{Recycling of lead batteries}

In India, which state that it is now the responsibility of each battery manufacturer, importer, assembler and recycler to ensure that the number of used lead-acid batteries collected is equal to the number of new leadacid batteries sold.

Lead batteries, accounting for $78 \%$ of reported global consumption in 2003.

By applying best available techniques for recycling, $<0.1 \%$ of the lead is lost by the recycling activities.

\section{Controlling lead release from the sources}

Reducing consumption of raw materials and products that include lead as an impurity.

Substitution (or elimination) of products, processes and practices containing or using lead with lead-free alternatives.

Controlling lead releases through lowemission process technologies and cleaning of off-gases and wastewater.

Management of lead-containing waste.

\section{Phytoremediation}

It describes the treatment of environmental problems (bioremediation) through the use of plants that mitigate the environmental problem without the need to excavate the contaminant material and dispose of it elsewhere. Phytoremediation has become an effective and affordable technological solution used to extract or remove inactive metals and metal pollutants from contaminated soil. Phytoremediation includes includes phytostabilisation, phytoextraction, phytovolatilisation, rhizofilteration etc.

Phytoextraction - To hyperaccumulate heavy metals in plant biomass.

Phytostabilization - Immobilisation of heavy metals in the soil or ground water through absorption or accumulation by roots.

Rhizofilteration - Adsorption/absorption of contaminant into plant roots present in solution surrounding root.

$\mathrm{Pb}$ is the least mobile heavy metal. Because $\mathrm{Pb}$ is very strongly bound in almost all types of soil, its phytoextraction is rather limited. When $\mathrm{Pb}$ is taken up by plants, its translocation to above-ground parts is very poor. The major proportion of $\mathrm{Pb}$ is concentrated in root tissues.

\section{Phytoextraction}

Phytoextraction is a soil remediation technique involving plants that concentrate heavy metals in their shoots, which may be removed from the area by harvest. Lead phytoextraction, using plants to extract $\mathrm{Pb}$ from contaminated soils, is an emerging technology. Calculations of soil $\mathrm{Pb}$ mass balance suggest that this technology will be economically feasible only if systems can be developed to employ high biomass plants that 
can accumulate greater than $1 \% \mathrm{~Pb}$ in their shoots (Huang et al., 1997).

\section{Chemically enhanced phytoextraction}

It has been demonstrated that $\mathrm{Pb}$ is rapidly accumulated in the roots if $\mathrm{Pb}$ is bioavailable in the plant growth media; however, only a small proportion of absorbed $\mathrm{Pb}$ is translocated to shoots. For most $\mathrm{Pb}$ contaminated soils that we have studied, $\mathrm{Pb}$ in soil solution is usually less than $0.1 \%$ of total soil $\mathrm{Pb}$. Thus, the $\mathrm{Pb}$ availability to plants is limited. Furthermore, for plants grown in these soils, $\mathrm{Pb}$ translocation from roots to shoots was less than $30 \%$ for the best $\mathrm{Pb}$ translocating plants (Huang et al., 1996, Jones et al., 1973, Kumar et al., 1995). Two major limitations to the $\mathrm{Pb}$ phytoextraction are the low $\mathrm{Pb}$ bioavailability in soil and the poor $\mathrm{Pb}$ translocation from roots to shoots. A key to $\mathrm{Pb}$ phytoextraction is to increase and maintain $\mathrm{Pb}$ concentrations in the soil solution. Chelates have been used in soils and nutrient solutions to increase the solubility of metal cations in plant growth media and are reported to have significant effects on metal accumulation in plants (Grath et al., 2002) (Huang et al., 1997)

\section{Current approaches to revegetation and reclamation of $\mathrm{Pb}$ contamination}

Though application of synthetic chelates have shown promising effect on enhancing the translocation of metal contaminants from soil to above ground plant part; more particularly soil, synthetic chelates also increase the solubility of metal contaminants which can lead to leaching of metal to deep below the ground and thus contaminating ground water. Further reclamation of mined soil where probability of $\mathrm{Pb}$ contamination is more, revegetation can be a useful tool for stabilizing the contaminated soil. A range of reclamation techniques is available for metalliferous substrates but only through the use of vegetation to stabilise mine wastes can complete longterm rehabilitation be achieved. Successful revegetation can be a permanent and visually attractive solution and, at the same time, be relatively inexpensive. A vegetation cover can be effective in providing the necessary surface stability to prevent wind-blow of contaminated particulates, and in reducing water pollution by interception of a substantial proportion of incident precipitation (Tordoff et al., 2000). Vegetation can return a large proportion of percolating water to the atmosphere through transpiration, thus reducing the concentrations of soluble heavy metals entering watercourses.

Lead is circulated in the environment, mainly due to anthropogenic activities. Poisoning in the environment has achieved global concern due to its toxic effect on the living organisms. Soil serves as both source and sink of $\mathrm{Pb}$. It's availability in soil is governed by organic matter, $\mathrm{pH}$, kind of clay, presence of $\mathrm{CaCO}_{3}$, etc. Plants derives bio-available $\mathrm{Pb}$ and accumulates $\mathrm{Pb}$ in root region, it's translocation to above root portion is very low. Phyto-remediation, chemical remediation and re-vegetation with application of suitable amendments and appropriate management practices near areas with high $\mathrm{Pb}$ concentration are efficient techniques in remediation of contaminated soils.

\section{References}

Adhikari, T., and Singh, M. V. (2003). Sorption characteristics of lead and cadmium in some soils of India. Geoderma, 114 (1), 81-92.

Appel, C., and Ma, L. (2002). Concentration, $\mathrm{pH}$, and surface charge effects on cadmium and lead sorption in three tropical soils. Journal of Environmental Quality, 31(2), 581-589. 
Blackford, L. S., Choi, J., Cleary, A., D'Azevedo, E., Demmel, J., Dhillon, I., and Stanley, K. (1997). Sca LAPACK users' guide (Vol. 4). siam.

Blake, K. C. H., and Mann, M. (1983). Effect of calcium and phosphorus on the gastrointestinal absorption of $203 \mathrm{~Pb}$ in man. Environmental research, 30(1), 188-194.

Boussen, S., Soubrand, M., Bril, H., Ouerfelli, K., and Abdeljaouad, S. (2013). Transfer of lead, zinc and cadmium from mine tailings to wheat (Triticum aestivum) in carbonated Mediterranean (Northern Tunisia) soils. Geoderma, 192, 227-236.

Cao, X., Ma, L. Q., Chen, M., Hardison, D. W., and Harris, W. G. (2003). Lead transformation and distribution in the soils of shooting ranges in Florida, USA. Science of the Total Environment, 307(1), 179-189.

Chen, Y. M., Lin, W. H., Lin, Y. A., Liu, C. C., and Wang, M. K. (2014). Remediation of lead-contaminated soil using dissolved organic carbon solutions prepared by wine-processing waste sludge. Geoderma, 235, 233-239.

Chopin, E. I. B., and Alloway, B. J. (2007). Distribution and mobility of trace elements in soils and vegetation around the mining and smelting areas of Tharsis, Riotinto and Huelva, Iberian Pyrite Belt, SW Spain. Water, Air, and Soil Pollution, 182(1-4), 245-261.

Davis, A., Drexler, J. W., Ruby, M. V., and Nicholson, A. (1993). Micromineralogy of mine wastes in relation to lead bioavailability, Butte, Montana. Environmental science and technology, 27(7), 1415-1425.

Dermont, G., Bergeron, M., Mercier, G., and Richer-Lafleche, M. (2008). Soil washing for metal removal: a review of physical/chemical technologies and field applications. Journal of Hazardous Materials, 152(1), 1-31.

Gambrell, R. P. (1994). Trace and toxic metals in wetlands - a review. Journal of environmental Quality, 23(5), 883891.

Heard, M. J., Chamberlain, A. C., and Sherlock, J. C. (1983). Uptake of lead by humans and effect of minerals and food. Science of the Total Environment, 30, 245-253.

Hesterberg, D. (1998). Biogeochemical cycles and processes leading to changes in mobility of chemicals in soils. Agriculture, ecosystems and environment, 67(2), 121-133.

Hettiarachchi, G. M., and Pierzynski, G. M. (2004). Soil lead bioavailability and in situ remediation of lead- contaminated soils: A review. Environmental progress, 23(1), 78-93.

Huang, J. W., and Cunningham, S. D. (1996). Lead phytoextraction: species variation in lead uptake and translocation. New phytologist, 134(1), 75-84.

Huang, J. W., Chen, J., Berti, W. R., and Cunningham, S. D. (1997). Phytoremediation of lead-contaminated soils: role of synthetic chelates in lead phytoextraction. Environmental Science and Technology, 31(3), 800-805.

James, H. M., Hilburn, M. E., and Blair, J. A. (1985). Effects of meals and meal times on uptake of lead from the gastrointestinal tract in humans. Human and Experimental Toxicology, 4(4), 401-407.

Johnson, C. E., and Petras, R. J. (1998). Distribution of zinc and lead fractions within a forest spodosol. Soil Science Society of America Journal, 62(3), 782789.

Jones, L. H. P., Clement, C. R., and Hopper, M. J. (1973). Lead uptake from solution by perennial ryegrass and its transport 
from roots to shoots. Plant and Soil, 38(2), 403-414.

Jung, M. C., and Thornton, I. (1996). Heavy metal contamination of soils and plants in the vicinity of a lead-zinc mine, Korea. Applied Geochemistry, 11(1), 53-59.

Kraft, M. E., and Scheberle, D. (1995). Environmental justice and the allocation of risk: the case of lead and public health. Policy Studies Journal, 23(1), 113-122.

Krishnamurti, G. S. R., Huang, P. M., Van Rees, K. C. J., Kozak, L. M., and Rostad, H. P. W. (1995). A new soil test method for the determination of plant- available cadmium in soils. Communications in Soil Science and Plant Analysis, 26(17-18), 2857-2867.

Kumar, P. N., Dushenkov, V., Motto, H., and Raskin, I. (1995). Phytoextraction: the use of plants to remove heavy metals from soils. Environmental science and technology, 29(5), 1232-1238.

Lambert, M., Pierzinski, G., Erickson, L., and Schnoor, J. E. R. R. Y. (1997). Remediation of lead-, zinc-and cadmium contaminated soils. Issues in Environmental Science and Technology (United Kingdom).

Lanphear, B. P., Matte, T. D., Rogers, J., Clickner, R. P., Dietz, B., Bornschein, R. L. and Rabinowitz, M. (1998). The contribution of lead-contaminated house dust and residential soil to children's blood lead levels: a pooled analysis of 12 epidemiologic studies. Environmental research, 79(1), 51-68.

Lark, R. M., and Scheib, C. (2013). Land use and lead content in the soils of London. Geoderma, 209, 65-74.

Li, J. X., Yang, X. E., He, Z. L., Jilani, G., Sun, C. Y., and Chen, S. M. (2007). Fractionation of lead in paddy soils and its bioavailability to rice plants. Geoderma, 141(3), 174-180.
Majer, B. J., Tscherko, D., Paschke, A., Wennrich, R., Kundi, M., Kandeler, E., and Knasmüller, S. (2002). Effects of heavy metal contamination of soils on micronucleus induction in Tradescantia and on microbial enzyme activities: a comparative investigation. Mutation Research/Genetic Toxicology and Environmental Mutagenesis, 515(1), 111-124.

Mendez, M. O., Neilson, J. W., and Maier, R. M. (2008). Characterization of a bacterial community in an abandoned semiarid lead-zinc mine tailing site. Applied and environmental microbiology, 74(12), 3899-3907.

Needleman, H. (2004). Lead poisoning. Annu. Rev. Med., 55, 209-222.

Nriagu, J. O. (1990). Global metal pollution: poisoning the biosphere? Environment: Science and Policy for Sustainable Development, 32(7), 7-33.

Pacyna, J. M., and Pacyna, E. G. (2001). An assessment of global and regional emissions of trace metals to the atmosphere from anthropogenic sources worldwide. Environmental Reviews, 9(4), 269-298.

Pain, D. J. (1991). Lead shot densities and settlement rates in Camargue marshes, France. Biological Conservation, 57(3), 273-286.

Qian, J., Wang, Z. J., Shan, X. Q., Tu, Q., Wen, B., and Chen, B. (1996). Evaluation of plant availability of soil trace metals by chemical fractionation and multiple regression analysis. Environmental Pollution, 91(3), 309315.

Risser, J. A., Baker, D. E., and Westerman, R. L. (1990). Testing soils for toxic metals. Soil testing and plant analysis, 275-298.

Sharma, P., and Dubey, R. S. (2005). Lead toxicity in plants. Brazilian journal of plant physiology, 17(1), 35-52. 
Steele, M. J., Beck, B. D., Murphy, B. L., and Strauss, H. S. (1990). Assessing the contribution from lead in mining wastes to blood lead. Regulatory Toxicology and Pharmacology, 11(2), 158-190.

Steinnes, E., Sjøbakk, T. E., Donisa, C., and Brännvall, M. L. (2005). Quantification of pollutant lead in forest soils. Soil Science Society of America Journal, 69(5), 1399-1404.

$\mathrm{Su}$, C. (2014). A review on heavy metal contamination in the soil worldwide: Situation, impact and remediation techniques. Environmental Skeptics and Critics, 3(2), 24.

$\mathrm{Su}$, C. (2014). A review on heavy metal contamination in the soil worldwide: Situation, impact and remediation techniques. Environmental Skeptics and Critics, 3(2), 24.

Tiwari, S., Tripathi, I. P., and Tiwari, H. L. Effects of Lead on Environment.

Tordoff, G. M., Baker, A. J. M., and Willis, A. J. (2000). Current approaches to the revegetation and reclamation of metalliferous mine wastes. Chemosphere, 41(1), 219-228.

Underwood, E. J. (1979). Trace elements and health: an overview. Philosophical
Transactions of the Royal Society of London B: Biological Sciences, 288(1026), 5-14.

Vassil, A. D., Kapulnik, Y., Raskin, I., and Salt, D. E. (1998). The role of EDTA in lead transport and accumulation by Indian mustard. Plant Physiology, 117(2), 447-453.

Verma, S., and Dubey, R. S. (2003). Lead toxicity induces lipid peroxidation and alters the activities of antioxidant enzymes in growing rice plants. Plant Science, 164(4), 645-655.

Wald, M. L. (2008). EPA proposes new limits on lead in the air, the first revision in 30 years. New York Times, 2.

Yang, J. Y., Yang, X. E., He, Z. L., Li, T. Q., Shentu, J. L., and Stoffella, P. J. (2006). Effects of $\mathrm{pH}$, organic acids, and inorganic ions on lead desorption from soils. Environmental Pollution, 143(1), 9-15.

Yang, Y. Y., Jung, J. Y., Song, W. Y., Suh, H. S., and Lee, Y. (2000). Identification of rice varieties with high tolerance or sensitivity to lead and characterization of the mechanism of tolerance. Plant Physiology, 124(3), 1019-1026.

\section{How to cite this article:}

Neelam Yadav, Ankita Trivedi, S.S. Yadav, D.K. Yadav, V.K. Yadav and Nagesh Yadav. 2018. Soil Pollution with Lead: Geochemistry, Food Safety Issues and Reclamation Options A Review. Int.J.Curr.Microbiol.App.Sci. 7(05): 528-538.

doi: https://doi.org/10.20546/ijcmas.2018.705.067 